\title{
世界結晶年記念講演会「結晶の美しい世界と, 私たちの未来」
}

\author{
大阪大学大学院工学研究科応用化学専攻 井上 豪
}

Tsuyoshi INOUE: Memorial Lectures of International Year of Crystallogaphy (IYCr) "Crystals: Beauty and our Future"

\section{1. はじめに}

平成 26 年 11 月 2 日 (日曜日) の午後 1 時, 東京大学本郷 キャンパス伊藤国際学術研究センターの伊藤謝恩ホール において世界結晶年日本委員会主催の記念講演会「結晶 の美しい世界と, 私たちの未来」が開催された。例年, 日本結晶学会年会は2 日間の日程で開催されるが, 今年 は「世界結晶年 International Year of Crystallography 2014 (IYCr2014)」を実質的に担当する学会として3日間 の開催となり，その中日に日本結晶学会主催の会員向け の記念シンポジウム (午前) と, 世界結晶年日本委員会主 催の一般向け記念講演会 (午後) を開催し, ご来賓をその まま日本結晶学会年会の懇親会にご招待するという流れ の中で開催された。特に，本記念講演会は 1 年間の IYCr2014の活動を締めくくる最も重要な記念行事と位置 付けられ，一般向けの広報にも力を入れた結果, 500 名が 収容可能な講演会場に延べ数では 400 名を超える来場者 を数えて成功裏に終えることができた.

\section{2. 記念講演会}

第 1 部では, これまでの 100 年間の日本における結晶 学の歴史を振り返った。司会役の日本委員会副委員長の 栗原和枝教授が，ラウエやブラッグらのノーベル賞受賞 の年に, 彼らより遙かに複雑で困難な課題に, 東京大学教
授の寺田寅彦や日本結晶学会初代会長の西川正治らが取 り組んでいたという事実を，このことが書かれている当日 配布の資料 (理研ニュース) を片手に熱弁を振われ, 講演 会が開始された。このことは, 日本委員会委員長の飯島澄 男先生のご挨拶, 日本学術会議会長の大西 隆会長や内閣 府政策統括官の倉持隆雄様 (科学技術イノベーション担 当）のご祝辞のあと,「寺田寅彦からの 100 年」と題した, 同じ東京大学の雨宮慶幸講師からもご紹介をいただいた。

第 2 部では,「結晶が魅せる美しい世界」と題して 5 名 の著名な先生方にご講演をいただいた，まずは，寺田寅彦 教授の弟子の 1 人で, 1936 年に世界初の人工結晶の作製 に成功した北海道大学教授の中谷宇吉郎先生のご息女の 3 人 (中谷オルセン咲子講師, 中谷芙二子講師, 中谷三代 子講師; それぞれ地質学者, 芸術家, ピアニストとして世 界的にも著名）が揃ってお見えになられ，ご講演をいただ いた. 名城大学の飯島澄男講師によるカーボンナノチュー ブの発見とその応用に関するお話や, 東京理科大学の中井 泉講師による 300 年前の芸術品を復活させるお話は, 夕イ トルのとおり, 一般参加の方々のみならず結晶学会会員を も魅了した.

続く第3 部「結晶からうまれる私たちの未来」では, 佐 藤勝昭講師, 佐川眞人講師, 井上晴夫講師, 後藤俊男講師 に「結晶」が拓く最先端の科学技術についてご紹介いた だいた. 折しも赤坂・天野・中村らの 3 氏が青色 LEDを

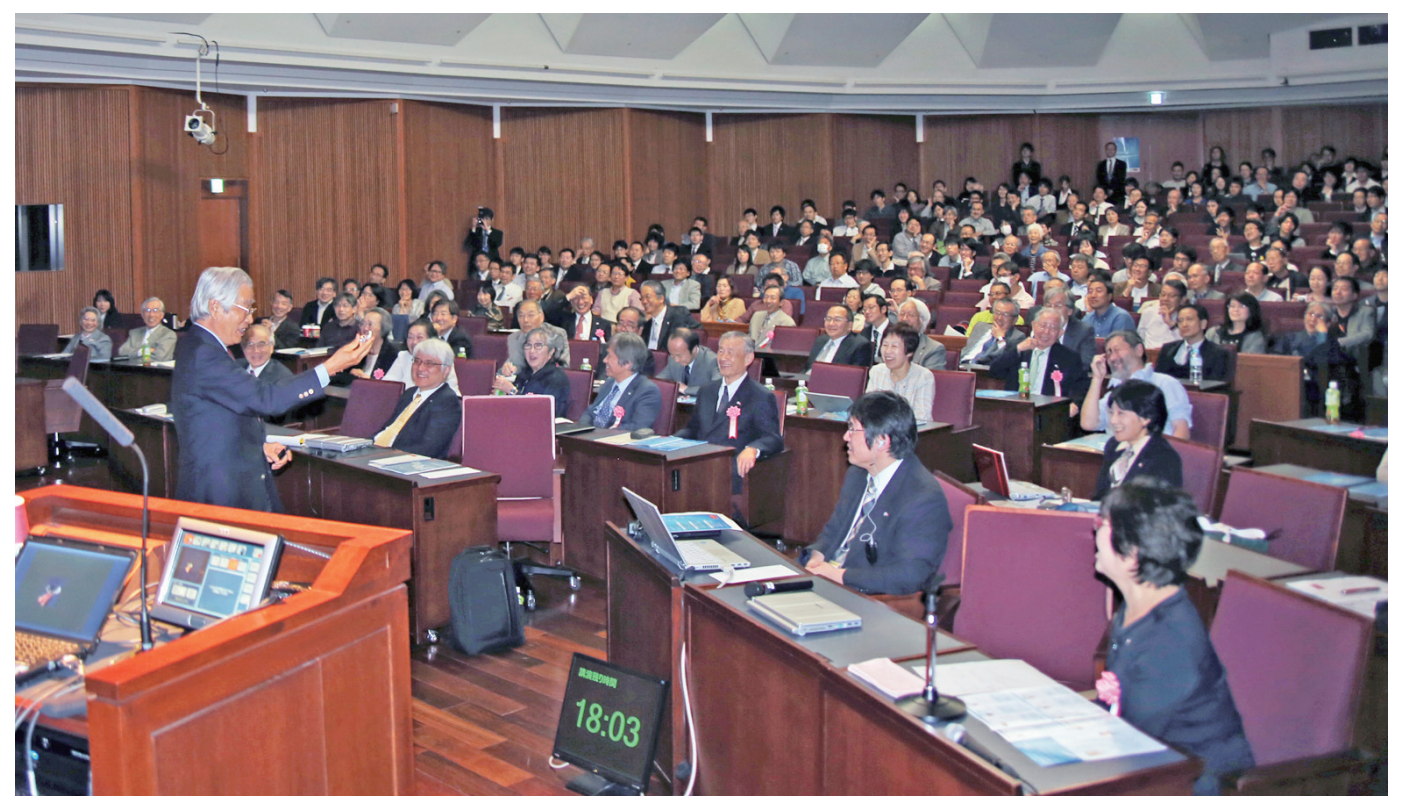

飯島澄男先生（世界結晶年日本委員会委員長） 


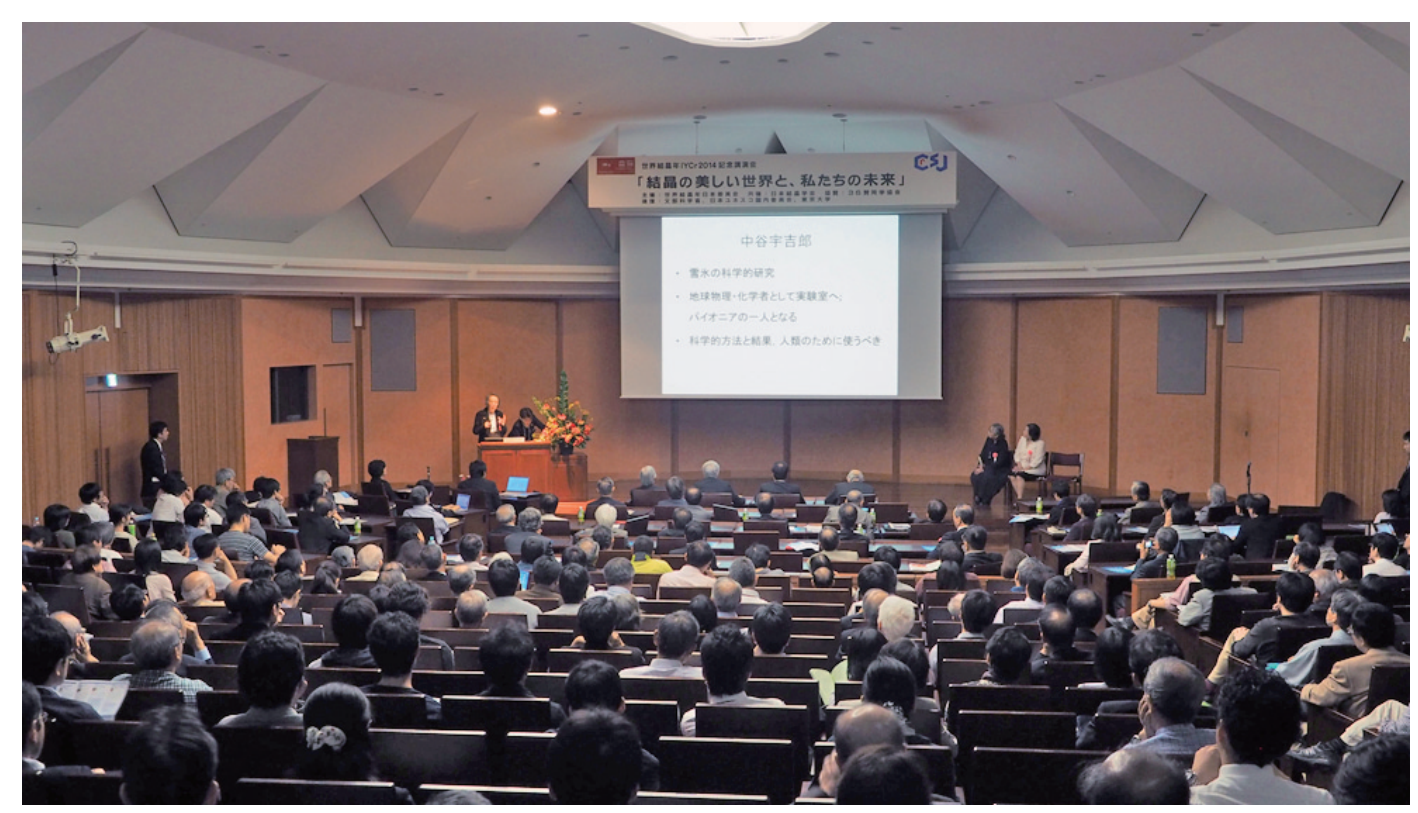

講演会場の様子 (中谷オルセン咲子先生の講演時)

発する人工結晶の発明でノーベル物理学賞を受賞した直 後とあって参加者らの関心も高く, 講師の先生からいた だいた「半導体」「永久磁石」「人工光合成」「新薬」の開 発に繋がる科学技術の進歩と未来への提言は, 研究者に とっても大きな刺激となった.

\section{3. 企画運営}

当日の運営に奔走していたこともあり,すべてのご講 演を隅から隅まで洀聴できたわけではないが，最後に元 国際結晶学連合会長の大橋裕二先生が閉会のご挨拶の中 で述べられたとおり, 次の 100 年の科学技術の発展に期待 し, 日本や世界の人々の将来の暮らしに明るい希望を抱 かせる良い記念本講演会になったと確信している.

大変に㧍忙しい中，日程を調整していただいてお越し いただいた講師の先生方には改めて沿く感謝申し上げた い. また, 本講演会途中は 1 時間遅れで進行するなど大変 に心配する場面もあったが，第 2 部と第 3 部の司会を務 めていただいた理化学研究所理事の川合眞紀先生, 東京 理科大学教授の黒田玲子先生らの機転で大幅に修正して いただいた. 大変失礼ながら時間の短縮に応じて下さっ た講師の先生方にもこの場を扮借りして抒詫び申しあげ たい.

なお，本記念講演会を開催するにあたり，文部科学省， ユネスコ国内委員会, 東京大学から協賛をいただいた。 た, IYCr2014の趣旨の 1 つである次世代の科学技術を担 う「若手の育成」のため, 本学会をはじめ 37 を数える賛同 学協会の空口を通じて若手会員や, 全国200を超えるスー
パーサイエンス高校 (SSH) にもポスターやリーフレット を送付して広報をお願いした. 特にパンフレット「結晶」 は全部で 2 万部を印刷して広報に務めたが，これら広報に 必要な費用は, 理化学研究所, (株りガク, 日本電子, 浜松 ホトニクス, 高エネルギー加速器研究機構から多額の寄付 を頂戴した。一方, 読売新聞, 朝日新聞, 毎日新聞, 日本経 済新聞, 日刊工業新聞, 公明新聞の各新聞社からは, IYCr2014の趣旨に賛同し，積極的に広報にご協力をいた だくとともに, 本記念講演会の運営に必要な資金の一部は 日本製薬工業連合会を通じ製薬企業 77 社からも寄付も頂 戴した. 関係各位にはこの場をお借りして心より感謝申し 上げる.

\section{4. おわりに}

今回, 世界結晶年日本委員会の下に発足した実行委員会 の庶務幹事として, 1 年間を通じて $\mathrm{IYCr} 2014$ の種々の活 動に参加させていただいた. 100 年に 1 回の記念すべき夕 イミングに実行委員会のメンバーとして, 委員長の高田昌 樹先生をはじめ, たくさんの先生方と思いや時間を共有で きたことに改めて感謝申し上げるとともに, 本記念講演会 の開催にあたりいつも温かい声援を送って励ましていた だた関係各位に改めて深く御礼を申し上げたい. 最後 に, 研究室の秘書の竹市未帆さんには, IYCr2014の事務局 として,この夏以降のほとんどの休日を返上して対応して いただいた. IYCr2014の委員会が発足した準備の段階か らずっと陰で支えていただいたことに改めて梁く感謝の 意を表したい。 